\title{
"Ceria”
}

Jurnal Pendidikan Anak Usia Dini

ISSN 2301-9905

Volume 11, No. 2, Januari 2020

Fakultas Keguruan dan Ilmu Pendidikan- Universitas Muhammadiyah Tangerang

\section{Upaya Meningkatkan Kemampuan Membaca Permulaan AnakUsia 5- 6 Tahun Melalui Media Puzzle di PAUD Flamboyan Sukasari Kota Tangerang}

\author{
${ }^{1}$ Ratih Fitri Astuti, ${ }^{2}$ Ratna Istiarini \\ 1,2Program Studi Pendidikan Guru Pendidikan Anak Usia Dini Fakultas Keguruan \\ Dan Ilmu Pendidikan Universitas Muhammadiyah Tangerang \\ e-mail:1ratihfitriastuti02i@gmail.com,2ratnaistiarini@gmail.com
}

\begin{abstract}
Abstrak
Penelitian ini bertujuan untuk mengetahui Kemampuan Membaca Permulaan melalui media puzzle pada anak didik kelompok B PAUD Flamboyan Sukasari Kota Tangerang. Metode yang digunakan adalah penelitian tindakan kelas (PTK) yang dilakukan sebanyak tiga (3) siklus. Prosedur penelitian ini terdiri dari 4 tahap yaitu perencanaan tindakan, pelaksanaan tindakan, observasi dan refleksi. Metode pengumpulan data yang digunakan dalam penelitian ini adalah metode observasi, wawancara dan dokumentasi. Subjek penelitin ini adalah anak didik kelompok B anak yang mengalami masalah kemampuan membaca permulaan, seperti menyebutkan simbol-simbol huruf vokal dan konsonan, menghubungkan lambang huruf vokal dan konsonan dengan gambar yang berawalan huruf vokal dan konsonan, membaca dan menulis nama sendiri. Hasil penelitian menunjukkan bahwa terjadi peningkatan kemampuan membaca permulaan melalui Media Puzzle. Kemampuan Membaca Permulaan pada Siklus I mencapai 51\%, Siklus II meningkat mencapai $74 \%$ dan meningkat lebih baik lagi pada Siklus III mencapai $91 \%$. Dengan demikian dapat disimpulkan bahwa variasi dalam pembelajaran memiliki peranan penting dalam penelitian meningkatkan kemampuan membaca permulaan melalui media puzzle. Dengan demikian terbukti bahwa penerapan melalui media puzzle dapat meningkatkan kemampuan membaca permulaan anak kelompok B di PAUD Flamboyan Kel.Sukasari Kec.Kota Tangerang.
\end{abstract}

Kata kunci : Kemampuan Membaca Permulaan, Media Puzzle, Anak Usia 5-6 Tahun.

\section{Pengantar}

Anak usia dini merupakan masa yang tepat untuk melakukan pendidikan. Pada masa ini, anak sedang mengalami proses pertumbuhan dan perkembangan yang luar biasa pesat. Pendidikan anak usia dini pada dasarnya meliputi seluruh upaya dan tindakan yang 
dilakukan oleh pendidik dan orang tua dalam proses perawatan, pengasuhan dan pendidikan anak.

Salah satu aspek yang harus dikembangkan pada Anak Usia Dini adalah aspek bahasa. Aspek perkembangan bahasa sangatlah perlu diperkembangkan karena dengan berbahasa anak dapat memahami kata dan kalimat serta memahami hubungan antara bahasa lisan dan tulisan. Kemampuan membaca pada Anak Usia Dini disebut dengan istilah kemampuan membaca permulaan. Kemampuan membaca permulaan dapat diketahui pada aktivitas visual yang melibatkan pemahaman simbol atau

tulisan. Menurut Wicaksana (2013) dalam Muflikha (2013) membaca permulaan adalah :

Kesanggupan mengenal huruf satu persatu dan menggabungkan huruf tersebut menjadi kata yang sederhana. Agar anak dapat membaca dengan baik, anak harus diperkenalkan dengan satu persatu huruf abjad terlebih dahulu. Kemampuan anak dalam mengenal huruf dapat terlihat dari kemampuan anak dalam menyebutkan bunyi dan nama dari setiap huruf-huruf abjad.

Namun, berdasarkan hasil pengamatan pra penelitian yang dilakukan oleh peneliti pada hari Selasa tanggal 02 Mei 2019 di PAUD Flamboyan Sukasari, khususnya kelompok kelas B, didapatkan beberapa temuan terkait kemampuan membaca permulaan anak. Pengamatan pra penelitian yang dilakukan oleh peneliti ini menggunakan metode wawancara kepada responden yang merupakan guru di PAUD Flamboyan Sukasari, khususnya yang memang mengajar di kelompok kelas B.

Pada proses pembelajaran tidak semua standar tingkat pencapaian perkembangan anak dapat dicapai dengan secara maksimal, misalnya dalam pembelajaran membaca permulaan merupakan kegiatan yang membosankan dan anak merasa jenuh dengan kegiatan tersebut. Seperti yang terjadi di PAUD Flamboyan Sukasari, anak dengan usia 5-6 tahun kemampuan membaca permulaan masih rendah.

Berdasarkan hasil wawancara dengan salah satu responden, yang merupakan guru di kelompok kelas B PAUD Flamboyan Sukasari, responden tersebut menyatakan bahwa dari total 11 anak yang ada di kelas, ada 8 anak yang masih kesulitan dalam membaca permulaan. Responden tersebut juga menyampaikan bahwasannya, alasan 8 anak ini masih 
kesulitan dalam membaca permulaan dikarenakan anak-anak tersebut lamban dalam mengenal huruf, sehingga membuat mereka pun lambat dalam membaca.

Pada masa kanak-kanak, huruf dan kata-kata merupakan sesuatu yang abstrak bagi anakanak, oleh karena itu guru dan orang tua bisa membuatnya menjadi nyata dengan cara yang sederhana yaitu dengan menggunakan cara-cara yang menyenangkan dengan media yang menarik bagi anak usia dini. Salah satu media yang dapat digunakan adalah dengan menggunakan media puzzle.

Media puzzle merupakan permaianan menyusun kepingan gambar sehingga menjadi sebuah gambar yang utuh. Media puzzle sangat sering digunakan di Taman Kanak-Kanak karena media puzzle adalah salah satu bentuk permainan yang memiliki nilai-nilai edukatf. Menurut Ismail (2006) dalam Khumayah (2017) puzzle adalah permainan menyusun suatau gambar atau benda yang telah dipecah dalam beberapa bagian.

Menurut Djamarah dkk (1995, h. 120), media adalah alat bantu apa saja yang dapat dijadikan sebagai penyalur pesan guna mencapai tujuan pengajaran. Media sebagai alat bantu dalam proses mengajar adalah suatu kenyataan yang tidak dapat dipungkiri. Menurut Gagne (Sujiono,dkk, 2009, h. 8.4), media adalah berbagai jenus komponen dalam lingkungan anak yang dapat mendorong anak untuk belajar. Dari pemaparan diatas dapat disimpulkan bahwa media adalah alat bantu guru dalam proses belajar mengajar untuk menyampaikan pembelajaran yang sukar menjadi semakin asik dan menyenangkan.

Berdasarkan penjelasan diatas diketahui bahwa ada kondisi anak usia dini yang masih belum berkembang dalam kemampuan membaca permulaan. Media puzzle bisa menjadi salah satu alternatif metode pembelajaran yang baru dalam menyampaikan pembelajaran membaca kepada para siswa. Khususnya metode yang lebih menyenangkan dan membuat anak tidak merasa jenuh atau bosan.

\section{Metode}

Dalam penelitian ini penelitian menggunakan metode yang akan digunakan adalah metode penlitian kuantitatif dan kualitatif. Dalam penelitian ini peneliti menggunakan metode 
penelitian tindakan kelas (PTK). Dalam bahasa inggris, Classroom Action Research berarti penelitian tindakan kelas. Apabila dikaitkan dengan pembelajaran, metode adalah cara yang digunakan dalam membelajarkan anak. Menurut Mulyasa (2011, h.11) merupakan suatu upaya untuk mencermati kegiatan belajar sekelompok peserta didik dengan memberikan sebuah tindakan yang sengaja dimunculkan dan dilakukan oleh seorang guru bersama peserta didik untuk memperbaiki dan meningkatkan kualitas pembelajaran.

Pada dasarnya Penelitian Tindakan Kelas sangat khas, yaitu ditandai dengan adanya siklussiklus. Tahapan penelitian yang dilakukan dalam penelitian tindakan kelas ini yaitu perencanaan (Planning), penelitian tindakan (Acting), pengamatan (Observing), refleksi (Reflecting). Hal ini sesuai dengan model yang dikembangkan oleh menurut kurt lewin dalam Salahudin (2015, h.30).

Kehadiran penelitian di PAUD Flamboyan Sukasari, dilapangan pada saat penelitian sangat mutlak diperlukan, karena penelitian bertindak langsung mengamati penelitian dan menjadi pengumpul data dan pelapor dari hasil penelitian.

Dalam penelitian ini peneliti melakukan penelitian di PAUD Flamboyan Sukasari Kecamatan Kota Tangerang. Penelitian melakukan penelitian tindakan kelas ada kelompok B yang berjumlah 11 anak. Penelitian melakukan penelitian sejak 06 Mei 2019 sampai 22 Mei 2019.

Instrumen penelitian adalah suatu alat yang dapat digunakan untuk memperoleh, mengolah dan menginterprestasikan informasi yang diperoleh dari para responden yang dilakukan dengan menggunakan pola ukur yang sama. Instrumen adalah alat pada waktu penelitian digunakan untuk mengumpulkan data mengenai kemampuan membaca permulaan anak usia 5-6 tahun di PAUD Flamboyan Sukasari. Penelitian ini dikatakan berhasil apabila melalui media puzzle memang dapat meningkatkan kemampuan membaca permulaan.

Salah satu masalah yang berhubungan dengan semua jenis penelitian adalah validitas. Artinya, apakah penelitian memang telah dilaksanakan seperti seharusnya dan hasil yang diperoleh dapat dipercaya, tanpa adanya analisis statistik? Penelitian tindakan memang tidak mengharap adanya jawaban akhir untuk pertanyaan atau masalah, tetapi 
menginginkan adanya peningkatan (dan perubahan) pada praktik pengajaran melalui pengembangan praktisi/guru. Uji validasi yang peneliti gunakan adalah validasi internal. Menurut Siregar (2014, h. 216) validitas internal dapat dilakukan dengan berbagai macam cara antara lain dengan melakukan perpanjangan pengamatan, peningkatan ketekunan dalam penelitian, triangulasi, diskusi dengan teman sejawat, analisis kasus negatif dan member check.

\section{Hasil dan Pembahasan}

Penelitian ini dilaksanakan di PAUD Flamboyan Sukasari, Jl. Pegadilan Raya Balai Warga RW 012 Komp. Pengayoman Kel.Sukasari Kec.Kota Tangerang, Kota Tangerang. PAUD Flamboyan Sukasari ini memiliki 2 kelas yaitu kelompok A, B. Subyek penelitian adalah kelompok B yang berusia 5-6 tahun dengan jumlah 11 orang siswa yang terdiri dari 3 perempuan dan 8 laki-laki. Pada kelompok B perlu ditingkatkan kemampuan membaca permulaan karena usia 5-6 tahun, seharusnya sudah berkembang dengan baik, seperti halnya dalam mengenal huruf.

Penelitian tindakan kelas kelompok B di PAUD Flamboyan Sukasari, Kecamatan Kota Tangerang untuk mengembangkan kemampuan membaca permulaan pada anak usia 5-6 tahun melalui permainan media puzzle huruf dilaksanakan dalam 3 siklus.

Sebelum melaksanakan siklus-siklus, peneliti melaksanakan analisis pencarian fakta dengan melakukan observasi awal atau pra siklus. Dari data observasi yang dilakukan peneliti ternyata metode dalam belajar melalui kemampuan membaca permulaan anak membosankan dan jenuh. Akhirnya, membuat kemampuan membaca permulaan anak-anak di PAUD Flamboyan Sukasari masih kurang. Hal ini yang menyebabkan anak belum mampu menyebutkan simbol-simbol huruf yang dikenal, memahami hubungan antara bunyi dan bentuk huruf, membaca dan menulis nama sendiri dengan baik dan benar.

Perkembangan kemampuan membaca permulaan pada anak dapat dilihat, bila anak mampu menyebutkan simbol-simbol huruf yang dikenal, memahami hubungan antara bunyi dan bentuk huruf, membaca dan menulis nama sendiri. Tetapi, bila anak belum mampu hal tersebut maka anak disebut belum berkembang. 


\section{Grafik 1}

Observasi Prasiklus Kemampuan Membaca Permulaan

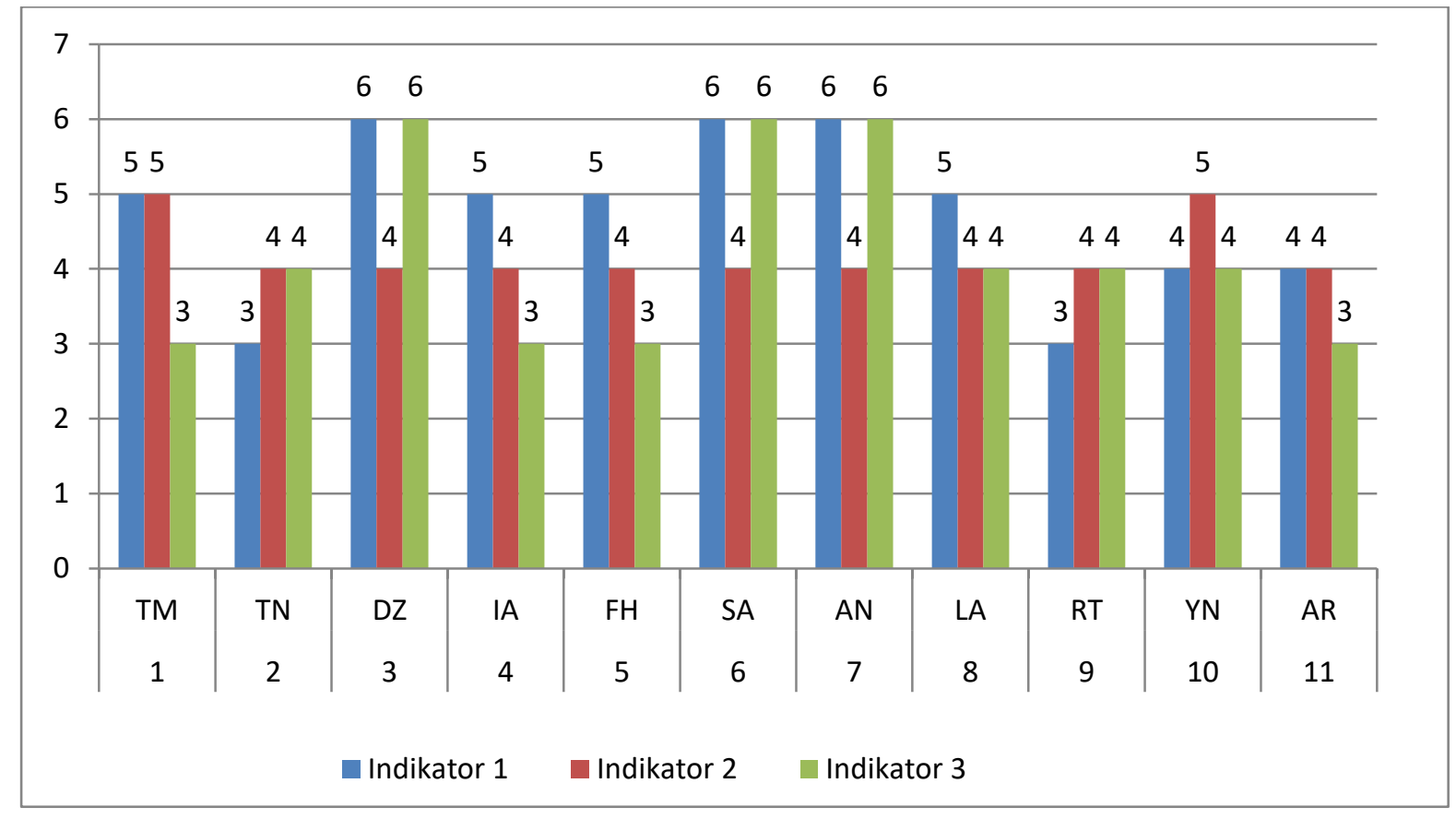

Berdasarkan hasil pengamatan yang dilakukan pada kondisi awal dari 11 orang anak di PAUD Flamboyan Sukasari (Kel B) dinyatakan hampir secara keseluruhan dalam tahap belum berkembang. Sehingga perkembangan kemampuan membaca permulaan anak pada kondisi awal masih belum ada peningkatan. Maka langkah selanjutnya yang akan dilakukan oleh peneliti agar perkembangan kemampuan membaca permulaan anak dapat meningkat adalah dengan menggunakan permainan media puzzle. Peneliti mencoba dengan upaya perbaikan menggunakan media puzzle dengan Penelitian Tindakan Kelas (PTK).

Berdasarkan pada permasalahan yang dihadapi oleh anak dalam perkembangan kemampuan membaca permulaan berbagai penyebab munculnya permasalahan, sebagaimana telah diuraikan pada bagian pendahuluan, dilakukan serangkaian tindakan untuk mengatasi permasalahan tersebut. Tindakan penelitian ini terdiri dari tiga siklus, dengan prosedur penelitian: penyusunan rencana tindakan, pelaksanaan, pengamatan atau observasi, dan refleksi. 
Kemampuan membaca permulaan anak usia 5-6 tahun di PAUD Flamboyan Sukasari terlihat terjadi peningkatan yang sangat signifkan dari kondisi awal hingga siklus III. Pada tindakan Siklus I peningkatan sebanyak 51\%, Siklus II 74\%, dan Siklus III peningkatan menjadi $91 \%$. Refleksi proses pembelajaran yang dilakukan oleh peneliti pada ketiga siklus ini menunjukkan hasil yang lebih baik.

Penggunaan media puzzle dalam kegiatan pembelajaran pada anak usia 5-6 tahun di PAUD Flamboyan Sukasari dapat meningkatkan kemampuan membaca permulaan. Peningkatan terjadi dalam penelitian yang dilakukan peneliti dalam 3 Siklus. Siklus I mengalami peningkatan $51 \%$, sedangkan pada Siklus II mengalami peningkatan $74 \%$ dan pada siklus III mengalami peningkatan yang signifikan yaitu 91\%. Peningkatan tersebut sesuai indikator pencapaian $75 \%$.

Berdasarkan hasil Siklus I menunjukkan adanya peningkatan kemampuan membaca permulaan. Hal ini terbukti dari perbandingan antara kondisi awal dan Siklus I. Dari data terlihat bahwa kondisi awal belum adanya peningkatan namun setelah diberikan tindakan pada Siklus I ada perubahan. Dari 11 anak, ada 7 anak berkategori masih berkembang, dan 4 anak berkembang sesuai harapan. Dari hasil analisis observasi lapangan, rata-rata kemampuan membaca permulaan anak berkisar pada $51 \%$.

Refleksi proses pembelajaran yang dilakukan oleh peneliti pada siklus ini menunjukkan hasil yang lebih baik. Diterangkan bahwa secara keseluruhan anak belum mencapai indikator keberhasilan yang ditentukkan sehingga perlu dilakukan perbaikan disiklus II.

\section{Grafik 2}

\section{Hasil Kemampuan Membaca Permulaan Siklus I}




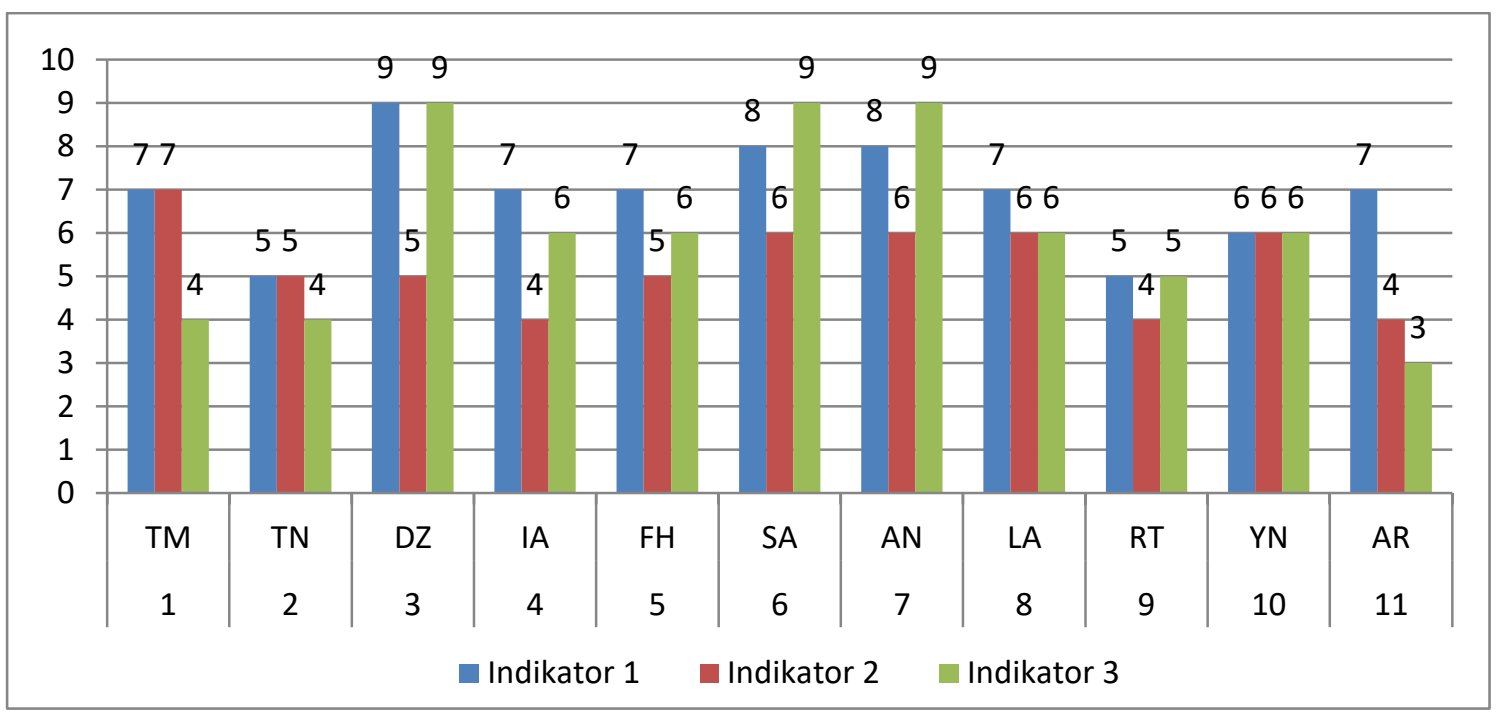

Berdasarkan hasil Siklus II menunjukkan adanya peningkatan kemampuan membaca permulaan. Dari 11 anak pada Siklus II ini seluruhnya berkatagori sesuai harapan (BSH). Dari hasil analisis observasi lapangan rata-rata kemampuan membaca permulaan dari Siklus I ke Siklus II berkisar pada rata-rata 74\%.

Refleksi proses pembelajaran yang dilakukan oleh peneliti pada siklus ini menunjukkan hasil yang lebih baik. Dari hasil diatas dapat diperoleh presentase Siklus II sebesar 74\%, diterangkan bahwa secara keseluruhan anak belum dapat mencapai indikator keberhasilan yang ditentukkan sehingga perlu dilakukan perbaikan di Siklus III.

Grafik 3

Hasil Kemampuan Membaca Permulaan Siklus II

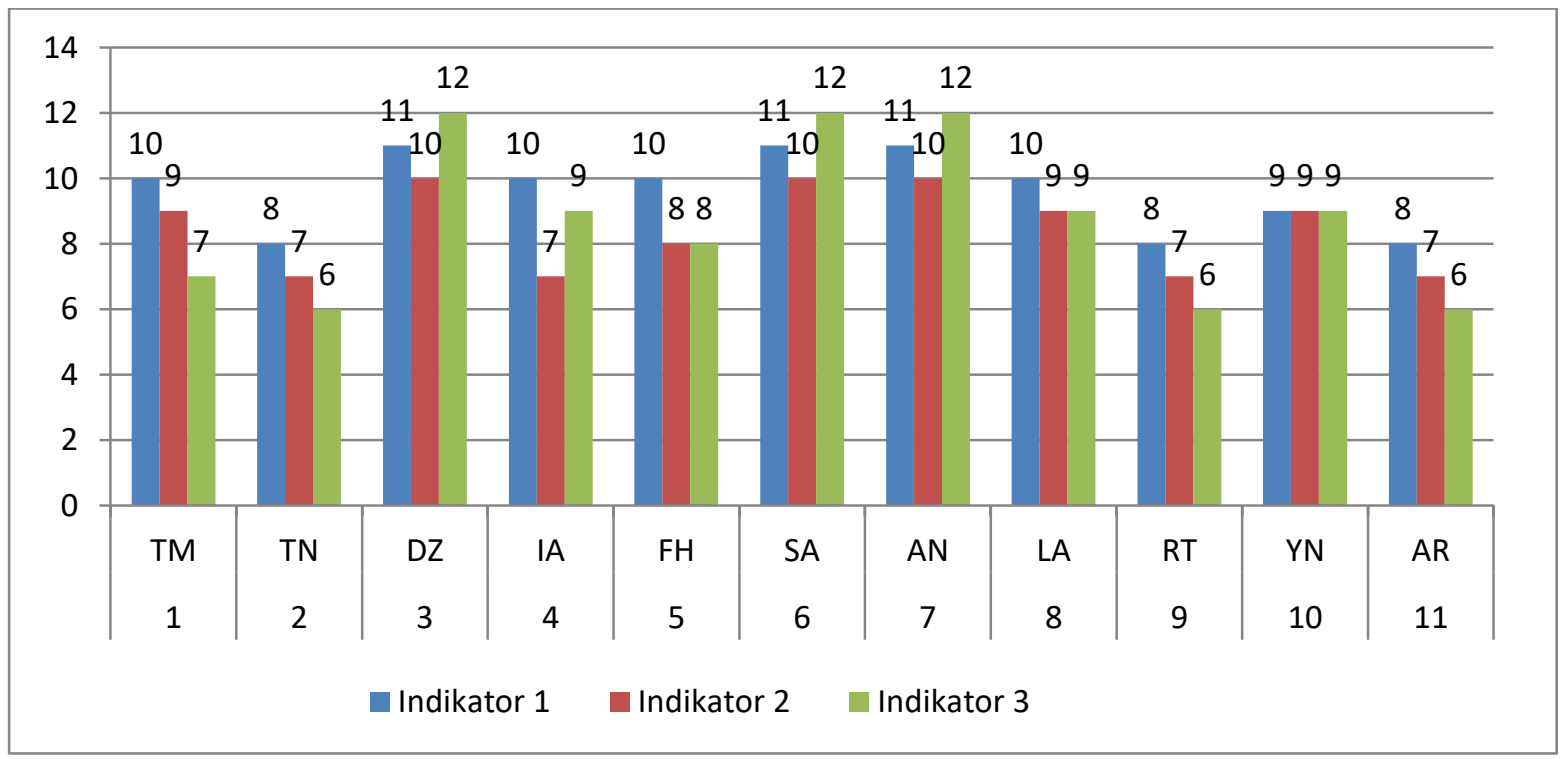


Berdasarkan pelaksanaan kegiatan pembelajaran pada Siklus II maka pada Siklus III pelaksanaan pembelajaran sudah berjalan dengan baik. Dari 11 anak pada Siklus III ini seluruhnya berkatagori Berkembang Sangat Baik (BSB). Dari hasil analisis observasi lapangan rata-rata kemampuan membaca permulaan dari Siklus II ke Siklus III berkisar pada rata-rata $91 \%$.

Dari hasil tindakan dan kolaborator memutuskan bahwa peneliti berhenti di Siklus III, karena perkembangan kemampuan membaca permulaan anak sudah meningkat secara signifikan mulai dari kondisi awal belum sama sekali ada peningkatan, Siklus I menjadi 51\%, Siklus II meningkat menjadi 74\%, dan Siklus III meningkat menjadi 91\%. Dari hasil observasi diketahui bahwa perkembangan kemampuan membaca permulaan anak usia 5-6 tahun di PAUD Flamboyan Sukasari dapat ditingkatkan melalui pembelajarann kemampuan membaca permulaan dengan menggunakan media puzzle.

Tingkat keberhasilan pelaksanaan Siklus I adalah 51\% anak sudah mulai aktif mengikuti kegiatan menyebutkan simbol-simbol huruf yang dikenal, memahami hubungan antara bunyi dan bentuk huruf, membaca dan menulis nama sendiri, pada Siklus II anak berhasil 74\%, sedangkan pada Siklus III anak berhasil 91\%. Jika ketiga siklus tadi dibandingkan maka Siklus II lebih berhasil dari Siklus I dan Siklus III berhasil dari Siklus II.

Kemampuan membaca permulaan anak usia 5-6 tahun di PAUD Flamboyan Sukasari terlihat terjadi peningkatan yang sangat signifikan dari kondisi awal hingga sampai Siklus III. Yaitu dari 11 anak seluruhnya berkategori Berkembang Sangat Baik (BSB). Pada tindakan Siklus I peningkatan sebanyak 51\%, Siklus II 74\%, dan Siklus III peningkatan menjadi $91 \%$. Refleksi proses pembelajaran yang dilakukan oleh peneliti pada ketiga siklus ini menunjukkan hasil yang lebih baik.

\section{Grafik 4}

\section{Hasil Kemampuan Membaca Permulaan Siklus III}




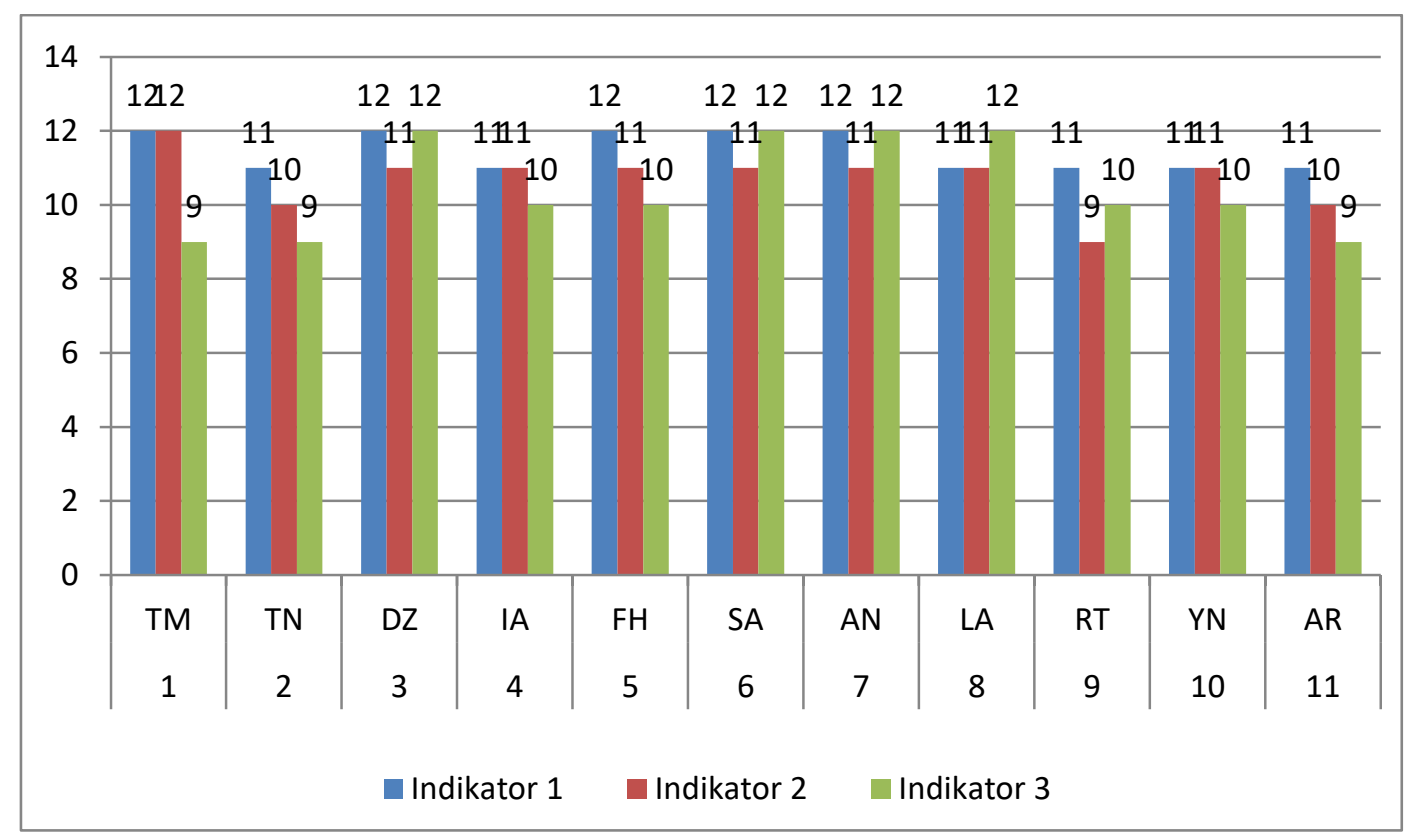

Kegiatan Pembelajaran Media Puzzle di PAUD Flamboyan Sukasari dalam Meningkatkan Kemampuan Membaca Permulaan Usia 5-6 Tahun. Dari hasil penelitian diperoleh keterangan bahwa kegiatan pembelajaran media puzzle dilakukan dengan persiapan yang cukup matang. Melalui persiapan pembuatan rencana pelaksanaan pembelajaran harian (RPPH). Peneliti juga mempersiapkan media puzzle yang menarik sesuai dengan instrumen penelitian agar anak-anak senang dan tertarik memainkannya.

Pada kegiatan bermain puzzle anak dapat merangsang kemampuan matematika anak, yang dimainkan dengan cara membongkar pasang kepingan puzzle berdasarkan pasangannya. Hal ini senada dengan Patmonodewo (Misbach, Muzamil, 2010) tentang media puzzle, maka dapat disimpulkan bahwa media puzzle merupakan alat permainan edukatif yang dapat merangsang kemampuan matematika anak, yang dimainkan dengan cara membongkar pasang kepingan puzzle berdasarkan pasangannya.

Pada kegiatan bermain puzzle anak dapat merangkai atau menghubungkan potonganpotongan puzzle yang belum tersusun rapi menjadi bentuk yang utuh. Hal ini senada dengan Suyadi (2015 h. 155) permainan puzzle adalah merangkai potongan-potongan bergambar khusus yang dirancang untuk menstimulasi anak. Menurut Suriasumantri, (Susanto, 2011, h. 98) mengungkapkan bahwa bahasa pada hakikatnya merupakan cara belajar untuk mengatur jalan pikiran seseorang dengan maksud melalui bahasa ini 
seseorang akan dapat mengatur jalan pikirannya. Dengan menguasai bahasa dan berbagai teorinya, maka dimungkinkan seseorang dapat lebih sistematis dalam me-manage jalan pikirannya. Bermain puzzle huruf dapat mengontrol konsentrasi tangan dan otak anak untuk menyusun puzzle huruf menjadi urutan kata yang utuh. Selain itu, anak juga bisa mengucapkan kata dengan benar.

\section{Kesimpulan}

Kegiatan pembelajaran puzzle huruf pada anak usia 5-6 tahun di PAUD Flamboyan Sukasari, terjadi peningkatan kemampuan membaca permulaan pada anak, ini terlihat dari penelitian awal dari 11 orang anak yang belum mampu menyebutkan simbol-simbol huruf yang dikenal, memahami hubungan antara bunyi dan bentuk huruf, membaca dan menulis nama sendiri, setelah melakukan kegiatan bermain puzzle huruf, kemampuan membaca permulaan anak terjadi peningkatan yang signifikan dan dapat berkembang dengan baik.

Perkembangan kemampuan membaca permulaan anak usia 5-6 tahun di PAUD Flamboyan Sukasari setelah mendapat tindakan. Hal ini dibuktikan dengan adanya peningkatan, yakni dari siklus I 51\%\% dari 11 anak. Siklus II mengalami peningkatan sebesar 74\% dari 10 anak. Dan pada siklus III mengalami peningkatan sebesar 91\% dari 11 anak. Sehingga presentase kenaikan dari siklus I ke siklus II adalah sebesar $24 \%$ dan prosentase kenaikan dari siklus II ke siklus III adalah $18 \%$.

Terbukti dari hipotesis perkembangan kemampuan membaca permulaan pada anak usia 5-6 tahun dengan media puzzle setelah tindakan mengalami peningkatan yang signifikan. Media pembelajaran perlu disiapkan dengan baik agar menumbuhkan minat anak untuk melaksanakan kegiatan.

Berdasarkan hasil penelitian yang disimpulkan di atas, dan berdasarkan pengalaman peneliti selama melaksanakan penelitian di PAUD Flamboyan Sukasari, Kecamatan Kota Tangerang, peneliti memberikan saran untuk siswa dengan menggunakan media puzzle huruf dapat meningkatkan kemampuan membaca permulaan pada anak, caranya siswa difasilitasi berbagai media puzzle yang menarik serta siswa diberikan semangat dan dorongan saran untuk guru diharapkan media bermain puzzle huruf diterapkan pada 
proses pembelajaran di Pendidikan Anak Usia Dini dengan cara ini guru lebih bisa berkreasi mengembangkan peningkatan perkembangan kemampuan membaca permulaan anak. Guru juga harus menjadi model pada proses pembelajaran karena anak belajar dari model yang ditampilkan.

Saran untuk sekolah perlunya menyediakan media belajar sebagai penyampaian pesanpesan pendidik untuk anak usia dini, caranya dengan menyediakan media belajar untuk dan sarana prasarana yang sesuai untuk anak usia dini, sehingga anak-anak mudah untuk menerima pembelajaran yang dilaksanakan. Saran untuk Orang Tua agar lebih memperhatikan setiap perkembangan dan potensi yang dimiliki anak. Dan memahami pentingnya kemampuan membaca permulaan pada anak dengan memberikan pengajaran yang sesuai dengan suasana yang menyenangkan.

\section{Daftar Acuan}

Djamarah, S. B \& Zain, A (2006). Strategi Belajar Mengajar. Jakarta:Rineka Cipta.

Mulyasa. 2011. Praktik Penelitian Tindakan Kelas. Bandung: PT Remaja Rosdakarya.

Muzamil, Misbach, 2010, Pengertian Media Puzzle, [online], (https://www. academia.edu/9717051/, diakses tanggal 20 November 2018).

Muflikha.Elok Siti. 2013. Peningkatan Kemampuan Anak Mengenal Huruf Melalui MediaTutup Botol Hias di Paud Kenanga I Kabupaten Pesisir Selatan. Universitas Negeri Padang. Spektrum PLS Vol.1, No.1. https://scholar.google.co.id diakses pada tanggal 18 Desember 2018

Salahudin. Anas. 2015. Penelitian Tindakan Kelas. Bandung : Pustaka Setia.

Siregar, Syofian (2014). Statistika Deskriptif untuk Penelitian. Jakarta: Rajawali Pers.

Sujiono, Y.N (2009). Metode Pengembangan Kognitif. Jakarta: Universitas Terbuka.

Susanto, Ahmad. Drs (2011). Perkembangan Anak Usia Dini (Pengantar dalam berbagai Aspeknya). Jakarta: Prenada Media Group. 
Suyadi, (2015). Cerdas dengan Spiritual Education Games. Yogyakarta. Serambi Semesta Distribusi 